\title{
Link to the Land and Mino-Pimatisiwin (Comprehensive Health) of Indigenous People Living in Urban Areas in Eastern Canada
}

\author{
Véronique Landry ${ }^{1}\left(\mathbb{D}\right.$, Hugo Asselin ${ }^{2, *} \mathbb{C}$ and Carole Lévesque ${ }^{3}$ \\ 1 Institut de recherche sur les forêts, Université du Québec en Abitibi-Témiscamingue, 445 Boulevard de \\ l'Université, Rouyn-Noranda, QC J9X 5E4, Canada; veronique.landry@uqat.ca \\ 2 École d'études autochtones, Université du Québec en Abitibi-Témiscamingue, 445 Boulevard de l'Université, \\ Rouyn-Noranda, QC J9X 5E4, Canada \\ 3 Institut National de la Recherche Scientifique, Centre Urbanisation Culture Société, 385 rue Sherbrooke Est, \\ Montréal, QC H2X 1E3, Canada; carole.levesque@ucs.inrs.ca \\ * Correspondence: hugo.asselin@uqat.ca; Tel.: +1-819-762-0971 (ex. 2621)
}

Received: 21 October 2019; Accepted: 27 November 2019; Published: 28 November 2019

\begin{abstract}
Mino-pimatisiwin is a comprehensive health philosophy shared by several Indigenous peoples in North America. As the link to the land is a key element of mino-pimatisiwin, our aim was to determine if Indigenous people living in urban areas can reach mino-pimatisiwin. We show that Indigenous people living in urban areas develop particular ways to maintain their link to the land, notably by embracing broader views of "land" (including urban areas) and "community" (including members of different Indigenous peoples). Access to the bush and relations with family and friends are necessary to fully experience mino-pimatisiwin. Culturally safe places are needed in urban areas, where knowledge and practices can be shared, contributing to identity safeguarding. There is a three-way equilibrium between bush, community, and city; and mobility between these places is key to maintaining the balance at the heart of mino-pimatisiwin.
\end{abstract}

Keywords: Aboriginal people; urban; place attachment; land; health

\section{Introduction}

Indigenous culture, identity, knowledge, and practices are intimately linked to the land [1-3]. Relatedness to the land has even been said to be a determinant of Indigenous health and well-being [4]. Health of the land is thus directly related to health of the people [5-8]. Moreover, the intersection of people and land is reflected in cultural landscapes and cultural keystone places, which are tied to well-being $[9,10]$.

There have been repeated governmental attempts to cut off Indigenous peoples from their lands and cultures [4,11,12]. Furthermore, an increasing proportion of Indigenous people move to urban areas, either temporarily or permanently, for various reasons, including greater access to education, work, and services [13-15].

Indigenous well-being depends on access to culturally safe services and places where cultural identity is understood and can be expressed with confidence [16]. Access to natural areas within cities contributes to people's health and such places have even been called "therapeutic" [17]. Indigenous people living in cities have thus created—and benefit from— "urban indigenous therapeutic landscapes" [18]. They also attend to so-called "sacred groves", i.e., small natural sites they protect for their contribution to cultural identity and biodiversity conservation $[19,20]$. Spending time in therapeutic landscapes and sacred groves allows one to maintain the link to the land, in turn having beneficial effects on self-esteem and pride to belong to an Indigenous culture [18,21]. 
In North America, Indigenous peoples belonging to the Algonquian language family use the term mino-pimatisiwin, which could be loosely translated as "living the good life", to describe a state of harmony, well-being, and comprehensive health based on relationships, cultural identity, and connection to the land (Table 1). The mino-pimatisiwin concept is thus more encompassing than the biomedical concept of health (absence of illness). Interestingly, similar conceptions of a "good life" exist in several other areas around the world, for example, buen vivir or sumak kawsay for the Quechuas in Ecuador [22], kametsa asaiki for the Ashaninkas in Amazonia [23], tjukurpa for the Anangu people in Australia [24], hauora for the Māoris in New Zealand [25], and ubuntu in South Africa [26].

Table 1. Various spellings and meanings of the comprehensive health concept among different Algonquian peoples in Canada.

\begin{tabular}{|c|c|c|c|}
\hline People & Spelling & Meaning & Reference(s) \\
\hline \multirow{9}{*}{ Anishnaabe } & $\begin{array}{l}\text { Mino-pimadiziwin; } \\
\text { Minawaziwin }\end{array}$ & Good life; well-being & [27] \\
\hline & Minawasiwin & Well-being & [28] \\
\hline & Mno bmaadis & $\begin{array}{l}\text { Balance between all elements of life: physical, } \\
\text { emotional, mental, and spiritual }\end{array}$ & [29] \\
\hline & Bimadiziwin & Importance of balance for well-being & {$[30]$} \\
\hline & Bimaadiziwin & $\begin{array}{l}\text { Living a long, fruitful life in communion with } \\
\text { family, community, other-than-human } \\
\text { persons, the environment, the Creator, and } \\
\text { the spirit world }\end{array}$ & [31] \\
\hline & Mino madjisin & Well-being, harmony, and balance & {$[32]$} \\
\hline & Mnaamodzawin & Good life & {$[33]$} \\
\hline & Minododazin & $\begin{array}{l}\text { Holistic understanding of respect reaching } \\
\text { beyond oneself }\end{array}$ & {$[34]$} \\
\hline & Mino-bimaadiziwin & Vision of life and philosophy & [35] \\
\hline Atikamek & Miro matisiwin & - & {$[32]$} \\
\hline \multirow{4}{*}{ Cree } & $\begin{array}{l}\text { Miõo pimâtisiwin; } \\
\text { Mino-pimatisiwin; } \\
\text { Mino-pimatiseewin }\end{array}$ & Good living and healthy living & [36] \\
\hline & Mino-pimatisiwin & $\begin{array}{l}\text { Relations guide good conduct, which in turn } \\
\text { leads to mino-pimatisiwin }\end{array}$ & {$[37]$} \\
\hline & Miyuupimaatsiiun & $\begin{array}{l}\text { Being alive well, responsible toward the land, } \\
\text { able to hunt and fish on the land, to pursue } \\
\text { traditional activities, have access to good } \\
\text { food, appreciate life, and be in relation with } \\
\text { other community members. }\end{array}$ & {$[6,38-40]$} \\
\hline & Miyo-mahcihoyān & $\begin{array}{l}\text { Physical, emotional, mental, and spiritual } \\
\text { well-being }\end{array}$ & {$[41]$} \\
\hline Innu & Minu inniuin & - & {$[32]$} \\
\hline
\end{tabular}

In Canada, urban areas are increasingly important in the life paths of Indigenous people [42], more than half of the Indigenous population now living in cities. Knowing that the link to the land plays a major role in Indigenous people's health and well-being, our aim was to determine if Indigenous people living in urban areas can reach mino-pimatisiwin. We show that there is a three-way equilibrium between bush, community, and city; and that Indigenous people in urban areas have various ways to maintain their link to the land, notably by accessing culturally safe sites and embracing broader views of "land" (including urban areas) and "community" (including members of different Indigenous peoples). 


\section{Materials and Methods}

This research is based on a review of the literature on mino-pimatisizin and other related concepts as well as on 15 interviews with members of various Indigenous communities in Eastern Canada, recognized by their peers for their knowledge of mino-pimatisiwin and life in urban settings (Table 2). We first recruited the participants through purposive sampling of key informants we already knew from our networks of research collaborators, and then through snowball sampling where participants identified other key informants to include. We stopped recruiting new participants when we reached information saturation, i.e., when new interviews did not generate additional information [43].

Table 2. Participant characteristics.

\begin{tabular}{llll}
\hline ID & Gender & Age & People \\
\hline $\mathbf{1}$ & Woman & $18-29$ & Cree \\
$\mathbf{2}$ & Woman & $18-29$ & Cree \\
$\mathbf{3}$ & Man & $30-44$ & Cree \\
$\mathbf{4}$ & Woman & $30-44$ & Cree \\
$\mathbf{5}$ & Man & $30-44$ & Cree \\
$\mathbf{6}$ & Woman & $45-59$ & Anishnaabe \\
$\mathbf{7}$ & Man & $45-59$ & Anishnaabe \\
$\mathbf{8}$ & Man & $45-59$ & Cree \\
$\mathbf{9}$ & Man & $45-59$ & Anishnaabe \\
$\mathbf{1 0}$ & Woman & $45-59$ & Cree \\
$\mathbf{1 1}$ & Man & $\geq 60$ & Atikamek \\
$\mathbf{1 2}$ & Man & $\geq 60$ & Anishnaabe \\
$\mathbf{1 3}$ & Man & $\geq 60$ & Cree \\
$\mathbf{1 4}$ & Man & $\geq 60$ & Anishnaabe \\
$\mathbf{1 5}$ & Man & $\geq 60$ & Anishnaabe \\
\hline
\end{tabular}

Participants-10 men and 5 women belonging to different age groups-lived or had previously lived in cities for different reasons, most often related to work, education, or family. Only one participant was Atikamek; Cree participants were younger (only one $\geq 60$ years old); Anishnaabe participants were older (none $<45$ years old); and women participants were younger (none $\geq 60$ years old) and mostly Anishnaabeg (4/5). That being said, the representations of mino-pimatisiwin in urban settings did not differ markedly between participants.

Semi-directed interviews-each lasting between 1 and 2 hours-allowed participants to freely express their viewpoints, while ensuring that certain themes were addressed. We based the interview guide on social representations of the land within the Kitcisakik Anishnaabeg [44]. We considered three overarching themes to explore the importance of the link to the land to the mino-pimatisizin of Indigenous people living in urban areas: (i) the land, (ii) urban environments, and (iii) support from family and friends. We conducted a thematic analysis [45] with the NVivo software (Version 10, QSR International, Chadstone, Victoria, Australia).

We obtained a certificate from the Ethics Review Board of Université du Québec en Abitibi-Témiscamingue. Free, prior, and informed consent was granted by all participants, after we presented them with a form specifying the research objectives, the nature of their participation (along with the associated benefits and disadvantages), the confidentiality safeguards, and how data would be processed and disseminated. We respected the key principles of research ethics in indigenous contexts [46]. To respect the reciprocity principle, we offered a compensation to the participants in gratitude for sharing their knowledge. Following the interviews, participants had the possibility to comment on the results to ensure that their viewpoints were adequately conveyed. 


\section{Results and Discussion}

\subsection{Defining the Land}

Three elements emerged from the interviews regarding how the participants defined the land. First, the land was defined either spatially, conceptually, or spiritually. Second, urban areas were often included in the definition of the land. Third, representations of the land differed between generations, reflecting diverse life paths.

The interviews revealed the multidimensional character of the social representations of the land, as already shown in [44]. The land was defined as a physical space, with or without specific geographic boundaries. Some participants referred to their community's territory or to cultural landscapes, and explained why certain places were important [10]. Others mentioned that the land was symbolic, lacking clearly defined boundaries: "To me, the land is not associated to a precise place" (participant 10); "The land is nature, it is a spiritual land" (participant 15).

Well-being includes both cultural and political dimensions, according to the Cree [6]. The land, however, was not evoked in a technical or political way at first, e.g., by providing a legal definition or referring to land claims. While six participants noted a political dimension to the land, they only did so late in the interviews. They referred to their role and responsibility to defend the land [47], threatened and "eaten away" by logging companies, mining companies, and outfitters. Territorial loss is indeed one of the most important factors contributing to cultural stress in Indigenous communities $[4,48]$. The fact that the political dimension was addressed late in the interviews can be explained by the stated purpose of the interview, which was to talk about the link to the land and its role in health and well-being.

Many participants said the city is included within the land and that the link to the land can be maintained in urban areas: "I always say 'yes, I live in Val-d'Or, yes, I live in an urban area, but I'm still on Anishnaabe land'... I'm ok with that, with living the mino-pimatisiwin in the city" (participant 6). "The land is where I feel good. It's in nature, but also in town" (participant 1). "My perception is that I'm still on my land here (in Val-d'Or)" (participant 2).

Older participants more frequently referred to the land as "in the bush" compared to younger adults. The word Nopimik used in the Anishnaabe language to refer to the bush, also means "where I am from" [49]. Representations of the land are indeed different among generations, as shown in [12,50]. Milestone events have influenced many aspects of the lifestyle, for example, treaty signature, residential schools, intensification of natural resource exploitation, and climate changes. Transformations of the land have influenced people's lives more or less markedly depending on their age and life pathways.

In their quest for identity, teenagers want to explore new horizons, which often entails leaving the community (and/or the bush), but only to come back later: "As you get older, (the land) becomes more important. There was a time when (my kids) turned their back on the land, as I did myself (when I was their age), but now they're coming back" (participant 3). Mobility (even hypermobility) between the land, the community, and the city is characteristic of Indigenous people's lives in contemporary Canada [42,51].

\subsection{Link to the Land in Urban Environments}

Indigenous people can feel outside their traditional cultural zone in urban areas [15]: "I suffocate in the city. All this concrete blocks my spirit" (participant 11). "I realize the chock one can have (upon arriving in the city). In a community, if your kid is sick you can call the nurse and she'll say 'Perfect, I'll be there in 5 minutes'. Here in the city, you wonder where to go, who to ask?... In the community, when it's 4:00 PM, it's simple, I'm cooking supper, 'Come on in!' In the city, you have to plan a week ahead! It's more complicated. It's not easy, particularly if you're shy or if you have low self-esteem" (participant 3).

Participants found their own ways of nurturing their connection to the land, even when living in the city, including by creating small-scale places of cultural safety in private backyards or in public parks [15], where physical, symbolic, and spiritual relations to the land can be expressed. Feelings of security and trust are necessary to develop belonging to a place [16]. 
In the worldviews of Anishnaabe and other Algonquian peoples, all elements of the environment are alive and have a spirit, and people rely on these elements to connect with the land [29]. A participant indeed underlined the capacity of trees to cure and provide well-being, even in urban environments: "Just by seeing or touching a tree, talking to it, you feel better" (participant 15).

In urban areas, relationships between humans and nature occur mostly in public parks, gardens, and nature reserves [52]. Nevertheless, all participants said they travel to the bush or the community from time to time to reconnect with nature, meet with their extended family, strengthen their identity, and engage in cultural practices [15]: "I can find balance in the city. If I go through harsh times, I take a walk in the bush. I found ways to stay connected with nature: cross-country skiing, kayak" (participant 3).

The multidimensional character of the link to the land can be maintained in several ways, even in urban settings, as suggested in the report of the Royal Commission on Aboriginal Peoples [53]:

- Welcome visitors who live in the community or in the bush;

- Stay connected with community members with phones or social networks;

- Meet with other Indigenous people living in the city;

- Participate in cultural events (e.g., pow-wow and National Indigenous Day);

- Visit organizations and institutions providing culturally safe services;

- Defend one's culture, people, or community;

- Cook/eat/share traditional food;

- Respect oneself, adopt a healthy lifestyle;

- Respect nature;

- Be independent;

- Engage in outdoor activities (e.g., kayak, canoe, and walk);

- Speak Indigenous languages;

- Learn/teach traditional knowledge/practices (e.g., craft, songs, medicine, and smudging).

Certain traditional practices can be remodeled in urban settings, in spaces of "cultural recovery" $[15,54]$; however, to lay tobacco by a tree in an urban park or to engage in traditional activities on the shore of an urban river does not provide a full equivalent to life in the bush. In other words, the mere transfer of practices from one place to another is not sufficient.

Cultural practices take an important place in the participants' lives, either at work or in training (some have stressed the importance of Université du Québec en Abitibi-Témiscamingue's First People's Pavilion in Val-d'Or). Some participants worked in organizations offering services to urban Indigenous people or defending their rights, and mentioned that it provided meaning to their presence in the city and fed their identity; it allowed them to maintain connected with the land: "I keep my link to the land, thanks to my job with, and for my community, my people" (participant 5).

For most participants, it was important to be able to go in the bush occasionally, as it is a privileged place of knowledge transmission, healing, caring, and provisioning [44,55]. Young and old, women and men, have testified to the importance of the bush in their lives, for their health and well-being: "My home, it's in the bush. Many people belonging to my generation were born in the bush.... Today, the bush is a place where everyone finds healing... mino-pimatisiwin is to be well in your mind, in your heart" (participant 15). "The people of Pikogan take refuge in the bush, that's where we reconnect. We need that, it's in our blood" (participant 12).

Life in indigenous communities is not complete if it does not allow for occasional stays in the bush. The real "home" is the bush and both the community and the city are somehow "out" of home (or they are "incomplete" places). Lévesque [46] suggested that Indigenous mobility should not be framed as an opposition between community and city. The results presented here rather point to a three-way equilibrium between bush, community, and city [55].

The frequency and duration of stays in the bush vary from one person to another. According to the participants, health comes from the bush, which plays a role the city will never be able to play. A participant rather bluntly stated that "Those who don't go in the bush end up in the street" (participant 3), 
echoing Christensen's [56] finding that breakdowns in family and community, as well as detachment from cultural identity, can result in what she calls "spiritual homelessness". As Radu et al. [40] put it: "The constant interaction with the land, by knowing it with all five senses, guides individuals and provides what is needed to live in harmony with the environment, with each other, and with oneself. The reciprocal and dialogic relationship with nature provides not only the material needs but also the ethic, moral and spiritual underpinnings of living a good life".

A participant, who had returned to living in the bush after several years in his community, said he could feel his ancestors there and that he found a long-sought well-being. Several stories were shared of diabetes regulation, blood pressure stabilization, and even major improvement of children born with chronic health problems. The numerous benefits to health and well-being associated to living in the bush have been highlighted in several studies [40,57-60].

But going in the bush requires a right of access, a family hunting ground, and a place to stay. One must also have access to the bush, either by owning a car, knowing someone who has one, or by living close enough to go on foot or an all-terrain vehicle, snowmobile, or canoe. Workers with less flexible schedules might lack the time needed to go in the bush (long and/or frequent holidays). Access to the bush can thus be challenging for people living in urban environments, but also in communities. This is why, for example, the (Quebec) Cree School Board has instituted goose break and moose break within the curricular schedule, so that families can leave the community together to hunt.

A participant expressed her pride of getting by in the bush, while emphasizing that similar pride can be generated by overcoming the challenges associated to adaptation to the city. She even argued that "real nomads live in the city" (participant 10), thereby underlining the courage, adaptability, strength, and autonomy needed to establish in the city. Maintaining one's indigenous identity in the city through different cultural practices generates pride and nurtures self-esteem.

\subsection{Importance of Support from Family and Friends}

The family network provides support and creates a sense of solidarity among its members [50]. The family carries sharing and caring values that help maintain one's identity and are determinants of well-being $[4,30]$. The interviews revealed that solidarity networks extend into urban areas; Indigenous people in the city develop a broader sense of family and community, hence adjusting the values of sharing and caring to include members of all Indigenous peoples [34,61]. The extension of solidarity networks is favored by practices requiring peer participation: caring for someone, speaking an Indigenous language, and sharing traditional food [29]. The extension of solidarity networks and the practice of collective rituals in culturally safe places underscore the importance of urban organizations, such as Native Friendship Centres, to strengthen social identity [62]. A participant said that to find a state of balance in the city, she had to go to places frequented by other Indigenous people, "to be in touch with people like you, sharing your cultural identity, in the workplace, for example. To be in contact with your world, to practice cultural activities, but also to take your own place" (participant 8). When their families do not live in the city, Indigenous people surround themselves with people sharing similar experiences, hence broadening their definition of community: "When you are in an environment like Val-d'Or, the concept of people is broader: my people is Indigenous_Cree, Inuit, Innu, Anishnaabe, Atikamek" (participant 6).

Knowledge and practices are transmitted by parents or elders, usually in the bush [55]. The participants insisted on the importance to ensure that intergenerational connections be maintained, as well as the context in which knowledge and practices are transmitted, regardless of the place of residence. When a member is away from the family network, sharing rituals provides support and creates a feeling of solidarity that is crucial to well-being. Asselin and Drainville [51] have shown that there is a cyclical dynamic between bush, community, and city, with people moving from one to another according to changes in their lives. The participants emphasized the importance of facilitating such mobility. 


\section{Conclusions}

A strong link to the land is fundamental to Indigenous people's comprehensive health-mino-pimatisiwin. We show that Indigenous people living in urban areas embrace broader views of "land" (including urban areas) and "community" (including members of different Indigenous peoples). Access to the bush and relations with family and friends are necessary to fully experience mino-pimatisiwin. Culturally safe places are needed in urban areas, where knowledge and practices can be shared, contributing to identity safeguarding. There is a three-way equilibrium between bush, community, and city; and mobility between these places is key to maintaining the balance at the heart of mino-pimatisiwin.

Author Contributions: Conceptualization, H.A. and V.L.; data curation, V.L.; methodology, V.L., C.L., and H.A.; investigation, V.L. and H.A..; formal analysis, V.L., H.A., and C.L.; writing-original draft preparation, V.L.; writing-review and editing, V.L., H.A., and C.L.; supervision, H.A. and C.L.

Funding: This research was funded by scholarships to V.L. provided by the Social Sciences and Humanities Research Council of Canada (SSHRC), Northern Scientific Training Program (NSTP), and DIALOG Network.

Acknowledgments: The authors are thankful to all those who accepted to share their views on link to the land and mino-pimatisizin. Kitci mikwetc.

Conflicts of Interest: The authors declare no conflicts of interest.

\section{References}

1. Kana'iaupuni, S.M.; Malone, N. This land is my land: The role of place in Native Hawaiian identity. Hūlili Multidiscip. Res. Hawaii. Well-Being 2006, 3, 281-307.

2. Martin, T.; Girard, A. Le territoire «matrice de culture ». Recherches amérindiennes au Québec 2009, 39, 61-69.

3. Asselin, H. Indigenous forest knowledge. In Routledge Handbook of Forest Ecology; Peh, K., Corlett, R., Bergeron, Y., Eds.; Earthscan Routledge: New York, NY, USA, 2015; pp. 586-596.

4. Richmond, C.A.; Ross, N.A. The determinants of First Nation and Inuit health: A critical population health approach. Health Place 2009, 15, 403-411. [CrossRef] [PubMed]

5. Oneha, M.F. Ka mauli o ka 'oina a he mauli kanaka: An ethnographic study from an Hawaiian sense of place. Pac. Health Dialog 2001, 8, 299-311. [PubMed]

6. Adelson, N. "Being Alive Well": Health and Politics of Cree Well-Being; University of Toronto Press: Toronto, ON, Canada, 2004; p. 141.

7. Parlee, B.; Berkes, F.; Gwich'in, T. Health of the land, health of the people: A case study on Gwich'in berry harvesting in Northern Canada. Ecohealth 2005, 2, 127-137. [CrossRef]

8. Kingsley, J.; Townsend, M.; Phillips, R.; Aldous, D. "If the land is healthy... it makes the people healthy": The relationship between caring for Country and health for the Yorta Yorta Nation, Boonwerrung and Bangerang Tribes. Health Place 2009, 15, 291-295. [CrossRef] [PubMed]

9. Davidson-Hunt, I.; Berkes, F. Learning as you journey: Anishinaabe perception of social-ecological environments and adaptive learning. Conserv. Ecol. 2003, 8, 5. [CrossRef]

10. Cuerrier, A.; Turner, N.J.; Gomes, T.C.; Garibaldi, A.; Downing, A. Cultural keystone places: Conservation and restoration in cultural landscapes. J. Ethnobiol. 2015, 35, 427-448. [CrossRef]

11. Booth, A.L.; Skelton, N.M. Industry and government perspectives on First Nations' participation in the British Columbia environmental assessment process. Environ. Impact Asses. 2011, 31, 216-225. [CrossRef]

12. Basile, S. Le rôle et la Place des Femmes Atikamekw Dans la Gouvernance du Territoire et des Ressources Naturelles. Ph.D. Thesis, Université du Québec en Abitibi-Temiscamingue, Rouyn-Noranda, QC, Canada, 2017; 259p.

13. Clatworthy, S.; Norris, M.J. Aboriginal mobility and migration: Trends, recent patterns, and implications: 1971-2001. In Moving forward, Making a Difference; White, J.P., Wingert, S., Beavon, D., Maxim, P., Eds.; Aboriginal Policy Research Volume IV; Thompson Educational Publishing Inc.: Toronto, ON, Canada, 2007; pp. 207-234.

14. Peters, E.; Andersen, C. Introduction. In Indigenous in the City: Contemporary Identities and Cultural Innovation; Peters, E., Andersen, C., Eds.; UBC Press: Vancouver, BC, Canada, 2013; pp. 1-20. 
15. Wilson, K.; Peters, E. You can make a place for it. Remapping urban Aboriginal spaces of identity. Environ. Plan. D 2005, 23, 395-413. [CrossRef]

16. Brascoupé, S.; Waters, C. Cultural safety. Exploring the applicability of the concept of cultural safety to Aboriginal health and community wellness. J. Aborig. Health 2009, 5, 6-41.

17. Cheesbrough, A.E.; Garvin, T.; Nykiforuk, C.I.J. Everyday wild: Urban natural areas, health, and well-being. Health Place 2019, 56, 43-52. [CrossRef] [PubMed]

18. Wendt, D.C.; Gone, J.P. Urban-indigenous therapeutic landscapes: A case study of an urban American Indian health organization. Health Place 2012, 18, 1025-1033. [CrossRef] [PubMed]

19. Bhagwat, S.A.; Rutte, C. Sacred groves: Potential for biodiversity management. Front. Ecol. Environ. 2006, 4 , 519-524. [CrossRef]

20. Pradhan, A.; Ormsby, A.; Behera, N. Diversity, population structure, and regeneration potential of tree species in five sacred forests of western Odisha, India. Écoscience 2019, 26, 85-97. [CrossRef]

21. Berry, H.; Butler, J.; Burgess, C.; King, U.; Tsey, K.; Cadet-James, Y.; Rigby, W.; Raphael, B. Mind, body, spirit: Co-benefits for mental health from climate change adaptation and caring for country in remote Aboriginal communities. NSW Public Health Bull. 2010, 21, 139-145. [CrossRef]

22. Altmann, P. Good life as a social movement proposal for natural resource use: The Indigenous movement in Ecuador. Cons. J. Sustain. Dev. 2013, 10, 59-71.

23. Barletti, J.P.S. Les enjeux politiques du « bien-vivre » en Amazonie autochtone. Recherches amérindiennes au Québec 2012, 42, 49-61. [CrossRef]

24. Grieves, V. Aboriginal Spirituality: Aboriginal Philosophy, the Basis of Aboriginal Social and Emotional Wellbeing; Discussion Paper No. 9; Cooperative Research Centre for Aboriginal Health: Darwin, Australia, 2009.

25. Fitzpatrick, K. Hauora and physical education in New Zealand: Perspectives of Māori and Pasifika students. Waikato J. Educ. 2005, 11, 37-49. [CrossRef]

26. Settee, P. PIMATISIWIN: Indigenous Knowledge Systems, our Time has Come. Ph.D. Thesis, University of Saskatchewan, Saskatoon, SK, Canada, 2007; p. 288.

27. McGregor, E. Algonquin Lexicon, 4th ed.; River Desert Education Authority: Maniwaki, QC, Canada, 2004.

28. Lemoine, G. Dictionnaire Français-Algonquin; Le Travailleur: Chicoutimi, QC, Canada, 1909.

29. Wilson, K. Therapeutic landscapes and First Nations peoples: An exploration of culture, health and place. Health Place 2003, 9, 83-93. [CrossRef]

30. Lavallée, L. Balancing the medicine wheel through physical activity. Int. J. Indig. Health 2008, 4, 64-71. [CrossRef]

31. Spielmann, R. 'You're So Fat!' Exploring Ojibway Discourse; University of Toronto Press: Toronto, ON, Canada, 1998.

32. Regroupement des centres d'amitié autochtones du Québec (RCAAQ). Mino Madji8in: En Action Pour le Mieux-être des Autochtones Dans les Villes; RCAAQ: Montréal, QC, Canada, 2016; p. 50.

33. Manitowabi, D.; Shawande, M. The meaning of Anishinabe healing and wellbeing on Manitoulin Island. Pimatisiwin 2011, 9, 441-458.

34. Kooiman, H.; Macdonald, M.E.; Carnevale, F.; Pineda, C.; Nottaway, W.; Vignola, S. Minododazin: Translating an Algonquin tradition of respect into youth well-being in Rapid Lake, Quebec. Pimatisiwin 2012, 10, 1-16.

35. Rheault, D. Anishinaabe Mino-Bimaadiziwin-The Way of a Good Life; Debwewin Press: Peterborough, ON, Canada, 1999; p. 181.

36. McIvor-Girouard, R. Mino Pimatiseewin: A Content Analysis of the Aboriginal and First Nations Submissions to the Commission on the Future of Health Care in Canada. Master's Thesis, University of Manitoba, Winnipeg, MB, Canada, 2006.

37. Hart, M.A. Seeking Mino Pimatisiwin: An. Aboriginal Approach to Healing; Fernwood Publishing: Winnipeg, MB, Canada, 2002; p. 128.

38. Cree Board of Health and Social Services of James Bay (CBHSSJB). Miyupimaatisiiun: Building a Strong and Healthy Cree Nation. Strategic Plan to Improve Health and Social Services; CBHSSJB: Chisasibi, QC, Canada, 2004.

39. Tanner, A. The nature of Quebec Cree animist practices and beliefs. In La Nature des Esprits Dans les Cosmologies Autochtones; Laugrand, F.B., Oosten, J.G., Eds.; Presses de la Université Laval: Quebec, QC, Canada, 2008; pp. 133-150.

40. Radu, I.; House, L.M.; Pashagumskum, E. Land, life, and knowledge in Chisasibi: Intergenerational healing in the bush. Decolonization Indig. Educ. Soc. 2014, 3, 86-105. 
41. Graham, H.; Martin, S. Narrative descriptions of miyo-mahcihoyān (physical, emotional, mental, and spiritual well-being) from a contemporary néhiyawak (Plains Cree) perspective. Int. J. Ment. Health Syst. 2016, 10, 58. [CrossRef]

42. Lévesque, C. The presence of Aboriginal peoples in Québec's cities: Multiple movements, diverse issues. In Not Strangers in These Parts: Urban Aboriginal Peoples; Newhouse, D., Peters, E., Eds.; Policy Research Initiative: Ottawa, ON, Canada, 2003; pp. 22-34.

43. Davis, A.; Wagner, J.R. Who knows? On the importance of identifying "experts" when researching local ecological knowledge. Human Ecol. 2003, 31, 463-489. [CrossRef]

44. Saint-Arnaud, M.; Asselin, H.; Dubé, C.; Croteau, Y.; Papatie, C. Developing criteria and indicators for aboriginal forestry: Mutual learning through collaborative research. In Changing the Culture of Forestry in Canada: Building Effective Institutions for Aboriginal Engagement in Sustainable Forest Management; Stevenson, M.G., Natcher, D.C., Eds.; Canadian Circumpolar Institute Press: Edmonton, AB, Canada, 2009; pp. 85-105.

45. Wolf, S.A.; Klein, J.A. Enter the working forest: Discourse analysis in the Northeast Forest. Geoforum 2007, 38, 985-998. [CrossRef]

46. Asselin, H.; Basile, S. Éthique de la recherche avec les Peuples autochtones: qu'en pensent les principaux intéressés? Éthique publique 2012, 14, 333-345. [CrossRef]

47. Niezen, R. Defending the Land: Sovereignty and Forest Life in James Bay Cree Society; Routledge: New York, NY, USA, 2016.

48. Bartlett, J. Involuntary cultural change, stress phenomenon and Aboriginal health status. Can. J. Public Health 2003, 94, 165-166. [CrossRef]

49. Saint-Arnaud, M.; Papatie, C. Ejigabwîn: La foresterie à la croisée des chemins pour les gens de Kitcisakik. Recherches amérindiennes au Québec 2012, 42, 111-127. [CrossRef]

50. Bousquet, M-P. «Quand Nous Vivions Dans le Bois »: Le Changement Spatial et sa Dimension Générationnelle: L'exemple des Algonquins du Canada. Ph.D. Thesis, Université Paris X-Nanterre, Paris, France; Université Laval, Québec, QC, Canada, 2002.

51. Asselin, H.; Drainville, R. Are young Anishnaabeg in a tug-of-war between community and city? World Dev. Perspect. in press.

52. Pretty, J. The Earth Only Endures: On Reconnecting with Nature and Our Place in It; Earthscan Publication Limited: London, UK, 2007; p. 287.

53. Royal Commission on Aboriginal Peoples (RCAP). Report of the Royal Commission on Aboriginal Peoples; RCAP: Ottawa, ON, Canada, 1996.

54. Desbiens, C.; Lévesques, C.; Comat, I. "Inventing new places": Urban Aboriginal visibility and the co-construction of citizenship in Val-d'Or (Québec). City Soc. 2016, 28, 74-98. [CrossRef]

55. Basile, S.; Asselin, H.; Martin, T. Le territoire comme lieu privilégié de transmission des savoirs et des valeurs des femmes Atikamekw. Recherches féministes 2017, 30, 61-80. [CrossRef]

56. Christensen, J. 'Our home, our way of life': Spiritual homelessness and the sociocultural dimensions of Indigenous homelessness in the Northwest Territories (NWT), Canada. Soc. Cult. Geogr. 2013, 14, 804-828. [CrossRef]

57. Richmond, C.; Elliott, S.J.; Matthews, R.; Elliott, B. The political ecology of health: Perceptions of environment, economy, health and well-being among 'Namgis First Nation. Health Place 2005, 11, 349-365. [CrossRef]

58. Isaak, C.A.; Marchessault, G. Meaning of health: The perspectives of Aboriginal adults and youth in a northern Manitoba First Nations community. Can. J. Diabetes 2008, 32, 114-122. [CrossRef]

59. Kirmayer, L.J.; Sehdev, M.; Whitley, R.; Dandeneau, S.; Isaac, C. Community resilience: Models, metaphors and measures. J. Aborig. Health 2009, 5, 62-117.

60. Mundel, E.; Chapman, G.E. A decolonizing approach to health promotion in Canada: The case of the Urban Aboriginal Community Kitchen Garden Project. Health Promot. Int. 2010, 25, 166-173. [CrossRef] 
61. Cornellier, F. Vivre La Ville: L'expérience Sociale et Spatiale des Autochtones de Val-d'Or. Master's Thesis, Université de Montréal, Montréal, QC, Canada, 2010; p. 157.

62. Stets, J.; Burke, P. Identity theory and social identity theory. Soc. Psychol. Quart. 2000, 63, 224-237. [CrossRef]

(C) 2019 by the authors. Licensee MDPI, Basel, Switzerland. This article is an open access article distributed under the terms and conditions of the Creative Commons Attribution (CC BY) license (http://creativecommons.org/licenses/by/4.0/). 